ISSN 0258-7122 (Print), 2408-8293 (Online)

Bangladesh J. Agril. Res. 44(3): 439-451, September 2019

\title{
MORPHO-ANATOMICAL APPRAISAL OF SOME PULSE CROPS UNDER SALINITY STRESS
}

\author{
M. A. H. KHAN ${ }^{1}$, M. A. BASET MIA ${ }^{2}$, J. U. AHMED ${ }^{3}$ \\ M. A. KARIM ${ }^{4}$ AND M. M. H. SAIKAT ${ }^{5}$
}

\begin{abstract}
The experiment was conducted at the field and laboratory of the Department of Crop Botany, Bangabandhu Sheikh Mujibur Rahman Agricultural University, Salna, Gazipur during the period from December 2016 to March 2017 to find out the morpho-anatomical appraisal of some pulse crops of Fabaceae family under salinity stress. Seven pulse crops viz., Lentil var. BARI Masur-7, Mungbean var. BARI Mung- 6, Blackgram var. BARI Maskalai-1, Chickpea var. BARI Chola-9, Field pea var. BARI Motor-1, Grasspea var. BARI Khesari3 and Cowpea var. BARI Felon-2; two levels of salinity 0 and $8 \mathrm{dSm}^{-1}$ were imposed as experimental treatments. It was laid out in a completely randomized design with three replications. The $\mathrm{NaCl}$ was directly mixed to the dry soil. The soil $\left(6 \mathrm{~kg} \mathrm{pot}^{-1}\right)$ of each treatment was placed in plastic pots with drainage holes in the bottom. The results of the experiment revealed that, salt stress caused decrease in morphological attributes and also changed anatomical features. There was a significant variation in relative values $(\%)$ of plant height, root length (\%) root dry matter (\%) and shoot dry matter (\%) of seven selected pulse crop varieties due to the salinity stress. The highest percentage of relative plant height (92), relative root length (98), relative root dry weight (89) and relative shoot dry weight (72.8) were observed in cowpea followed by grass pea and the lowest percentage of relative plant height (51), relative root length (56), relative root dry weight (54) and relative shoot dry weight (48) were observed in lentil. The stem anatomical features were found similar changes in xylem and phloem area. Among the pulse crop varieties, cowpea and grass pea were performed better whereas lentil and black gram were found more susceptible species than the others according to their morphological and anatomical attributes.
\end{abstract}

Keywords: Salinity, pulse crops, morphology, anatomy

\section{Introduction}

Among the food crops grown in Bangladesh pulses occupy only 0.37 million hectares of land that is $4.48 \%$ of the total cropped area (BBS, 2017). But these

${ }^{1}$ Ph.D. Fellow, Department of Crop Botany, Bangabandhu Sheikh Mujibur Rahman Agricultural University (BSMRAU), Salna, Gazipur-1706 \& Scientific Officer, Agricultural Research Station, Bangladesh Agricultural Research Institute (BARI), Cumilla, ${ }^{2 \& 3}$ Professor, Department of Crop Botany, BSMRAU, Salna, Gazipur-1706, ${ }^{4}$ Professor, Department of Agronomy, BSMRAU, Salna, Gazipur-1706, ${ }^{5}$ Professor, Department of Genetics and plant breeding, BSMRAU, Salna, Gazipur-1706. 
crops have been cultivating since prehistoric times as a source of dietary protein and as an important component of legume crop diversification in the predominantly cereal based cropping pattern. These crops also can improve the soil nutrient status through symbiotic $\mathrm{N}_{2}$ fixation. Total production of pulse during 2015-16 in Bangladesh was around 0.412 million metric tons from 0.372 million ha of land at the rate of 0.96 metric ton per hectare (BBS, 2017). Among various abiotic stresses, soil salinity is the major factor that hampers the plant growth and development and yield. Salinity can limit growth and yield of plant in three ways through osmotic potential, creating ion toxicity, causing disarrangement and imbalance of ion uptake resulting disorders of enzyme activities and membrane vis-a-vis metabolic activities. Salt tolerant plants are capable of minimizing detrimental effects of salt stress by producing a series of anatomical, morphological and physiological adaptations such as an extensive root system and salt screening glands on the leaf surface (Marcum et al., 1998). Although physiological adaptations are crucial in identifying selection criteria against salt stress both halophytes and non-halophytes exhibit remarkable structural modifications when exposed to high salinities, particularly in leaf anatomy (Dickson, 2000). Such structural changes in response to salinity stress are not very much clear, but they certainly play a crucial role in combination with physiological attributes in tolerating the stress. It appears that little information is available regarding the effect of salinity on the morphology and anatomy of pulse crop. The present study, was therefore, carried out to investigate specific anatomical and morphological modifications of some pulse crops of Fabaceae family which might have played a significant role in finding out an avenue of breeding technique for developing salt tolerant crops. As such the experiment was undertaken to observe the morphology and micro morphology (anatomy) of some pulse crops under salt stress situation.

\section{Materials and Methods}

The experiment was conducted at the Vinyl house and laboratory of the Department of the Crop Botany, Bangabandhu Sheikh Mujibur Rahman Agricultural University (BSMRAU), Gazipur from December 2016 to March 2017. Seven cultivated pulse crop varieties of Fabaceae family, developed by the Bangladesh Agricultural Research Institute (BARI), namely, viz., Lentil var. BARI Masur-7, Mungbean var. BARI Mung- 6, Blackgram var. BARI Maskalai1, Chickpea var. BARI Chola-9, Field pea var. BARI Motor-1, Grasspea var. BARI Khesari -3 and Cowpea var. BARI Felon-2; were used in the experiment. The experiment was conducted in plastic pot using $6 \mathrm{~kg}$ of soils. There were three replications of each treatment namely: control and $8 \mathrm{dS} \mathrm{m}^{-1}$. The method suggested by Rowell (1994) was used to calculate the quantity of $\mathrm{NaCl}$ required for the preparation of each saline soil treatment. The $\mathrm{NaCl}$ was directly mixed to 
the dry soil. The soil $\left(6 \mathrm{~kg} \mathrm{pot}^{-1}\right)$ of each treatment was placed in plastic pots with drainage holes in the bottom. The pots were arranged on wooden benches of the vinyl house. Another treatment (Control) was maintained by using fresh or tap water on the pot.

Seeds of pulse crops variety were sown on 15 December 2016. After sowing of seeds light irrigation was given to ensure uniform germination of seeds. Recommended fertilizers namely N, P, K, S were used at the rate of 20, 20, 24 and $10 \mathrm{~kg} \mathrm{ha}^{-1}$ as urea, triple superphosphate (TSP), muriate of potash (MoP) and gypsum respectively. For the anatomical studies, the leaf samples were collected from control and salinity treatment of pulse crop varieties at 50 days after sowing. The cross sections $5 \mathrm{~cm}$ slices from the stem were chosen and softened in a mixture of glycerine. Then the sections were photographed with a digital photo-camera attached to light microscope at 10-40 X magnifications and image 4.0 software.

For the calculation of area of xylem and phloem, the following formula was used (Hameed et al., 2013):

Area $=\frac{\text { Maximumlength X Maximum width }}{4} \times \pi$ Where, $\pi=$ Constant $(22 / 7)$

This formula was derived from the area of circle, which is $\pi \mathrm{r}^{2}$, which was $\pi \mathrm{xd}$ (diameter) $/ 2 \times \mathrm{d} / 2$.

After 50 days of germination, plants were harvested for collection of data. The mean root dry weight was calculated for each treatment. After separation of roots the samples of stem, branch and leaf were dried in an electrical oven to a constant weight at $70^{\circ} \mathrm{C}$. Thereafter, the mean shoot dry weight was calculated for each treatment.

Relative data were calculated by using the following formula (Shaheenuzzamn, 2014).

Relative value $\frac{\text { Value of saline treated genotype }}{\text { Value of control genotype }} \times 100$

The collected data were analyzed statistically followed Completely Randomized Design by Statistix10 computer package programme (Gomez and Gomez 1984).

\section{Results and Discussion}

There was a significant variation in relative values of plant height (\%), root length, shoot length, root dry matter and shoot dry matter, stem xylem area of the seven selected pulse crop species due to induced of salt stress. 


\section{Relative Plant Height (\%)}

Significant variation was observed in relative plant height (\%) of seven selected pulse species as affected by salt stress (Figure1). However, the highest relative plant height $(92 \%)$ was observed in cowpea followed by grasspea $(84 \%)$ and the lowest $(51 \%)$ in lentil.

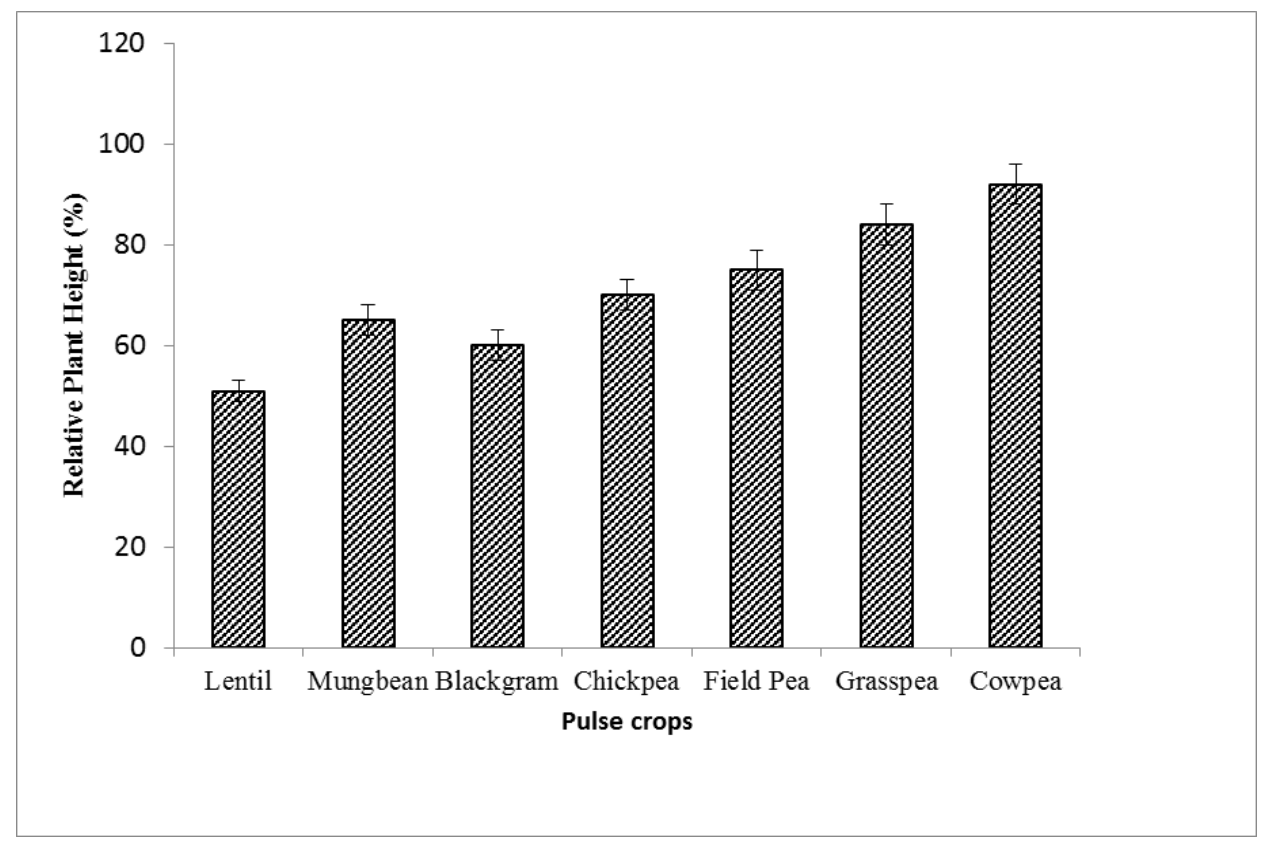

Fig. 1. Relative plant height (\%) of seven selected pulse crops under salt stress at 8 $\mathrm{dS} \mathrm{m}^{-1}$ used as commercial $\mathrm{NaCl}$; vertical bar represents standard error (SE).

Salinity reduces plant growth through osmotic and toxic effects and high sodium uptake ratio values cause sodicity, which increases soil resistance, reduces root growth, and reduces water movement through the root with a decrease in hydraulic conductivity also found that lentil appeared to be very salt sensitive (Katerji, et al. (2001).

\section{Relative Root Length (\%)}

Due to salt stress the relative root length (\%) of seven selective pulses crop varieties differed significantly (Figure3). The highest value (98\%) was found in cowpea which was statistically similar to grass pea (91.8) and the lowest relative value $(56 \%)$ was found in lentil. 


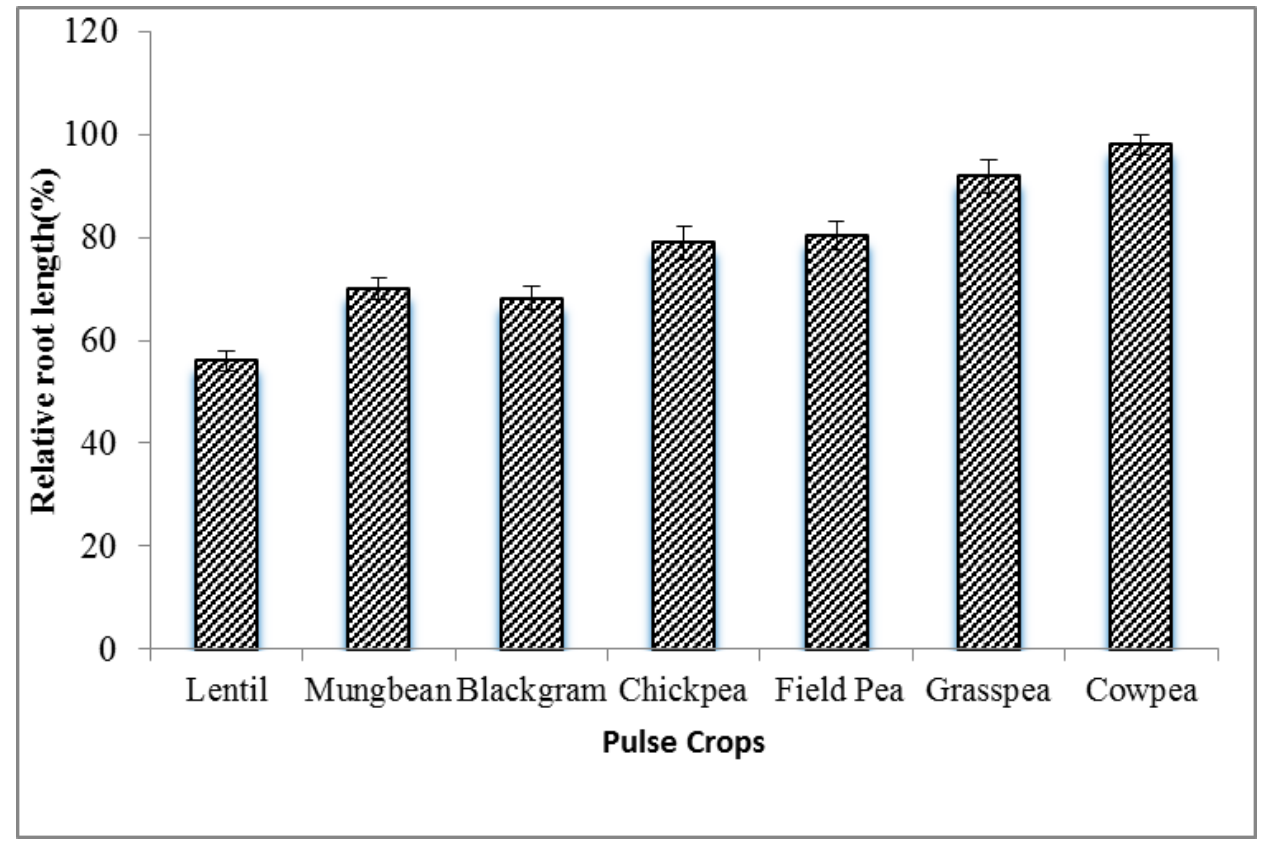

Fig. 3. Relative root length $(\%)$ of seven selected pulse crops under salt stress at 8 dSm-1 used as commercial $\mathrm{NaCl}$; vertical bar represents $\mathrm{SE}$.

The result elucidated that the increment of $\mathrm{NaCl}$ concentration caused the reduction of seedling root length of lentil. The result is in full agreement with those found by Duzdemiro et al. (2009) for pea. Root morphology is not only a very important factor for nutrient absorption by roots, but also it is very important for water uptake by roots from saline soils (Schleiff, 2008). Ouji et al. (2017) investigated that, $50 \mathrm{mMol}$ of salinity has a more pronounced effect on root length with respect to shoot length, as roots are directly exposed to salt solution. The reduction in root and shoot development might be due to toxic effects of the higher level of $\mathrm{NaCl}$ concentration as well as unbalanced nutrient uptake by the seedlings.

\section{Relative Root Dry Weight (\%)}

There was a significant variation in relative root dry weight $(\%)$ of the seven selected pulse crop varieties due to induced salinity stress (Figure 5). 


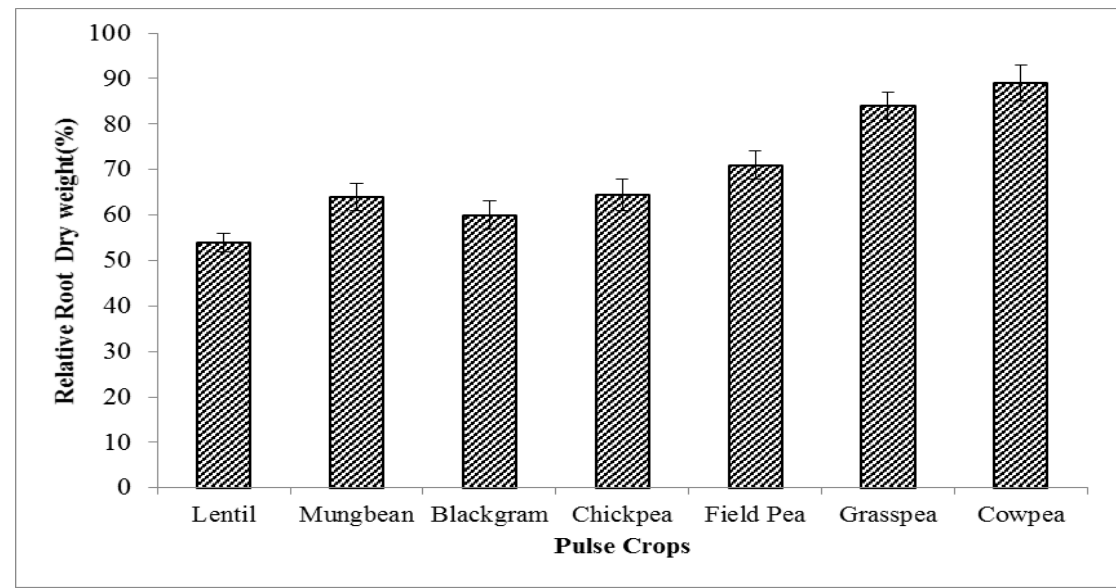

Fig 5. Relative root dry weight (\%) of seven selected pulse crops under salt stress at $8 \mathrm{dS}$ m-1 used as commercial NaCl; vertical bar represents SE.

The highest relative root dry weight (89\%) was observed in cowpea that was statistically similar to grass pea and the lowest (54\%) in lentil. This result is in agreement with Kaya et al., 2005. Taffouo et al. (2004) also found that the increase in salt concentration significantly reduced the production of dry weight at $50 \mathrm{mM}$ of $\mathrm{NaCl}$ in Glycine max and Phaseolus vulgaris.

\section{Relative Shoot Dry Weight (\%)}

Relative shoot dry weight (\%) was also reduced due to salinity stress of seven selected pulse crop varieties (Figure 6). However, the highest shoot dry weight was observed in cowpea and the lowest in lentil.

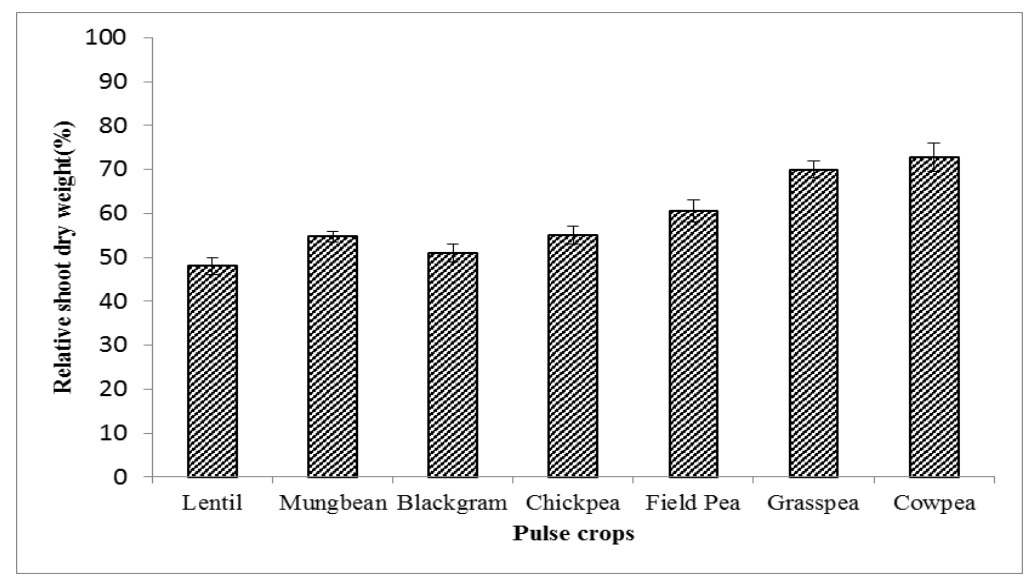

Fig. 6. Relative shoot dry weight (\%) of seven selected pulse crops under salt stress at $8 \mathrm{dSm}-1$ used as commercial $\mathrm{NaCl}$; vertical bar represents $\mathrm{SE}$. 
Salt stress reduced the growth of other grain legumes, including mungbean (Kabir et al., 2004), lentil (Bandeoglu et al., 2004). These growth reductions are often attributed to reductions in tissue water potential, indicating less water availability to cells which results in stomatal closure, reduced photosynthesis and inhibited growth (Garg and Manchanda, 2009).

\section{Relative Root and Shoot Dry Weight Ratio (\%)}

Due to salinity stress the relative root shoot dry weight ratio (\%) of seven selective pulse crop varieties did not differed significantly (Figure 7). However, the highest relative value (122.3\%) was found in cowpea and the lowest relative value $(112.5 \%)$ was observed in lentil.

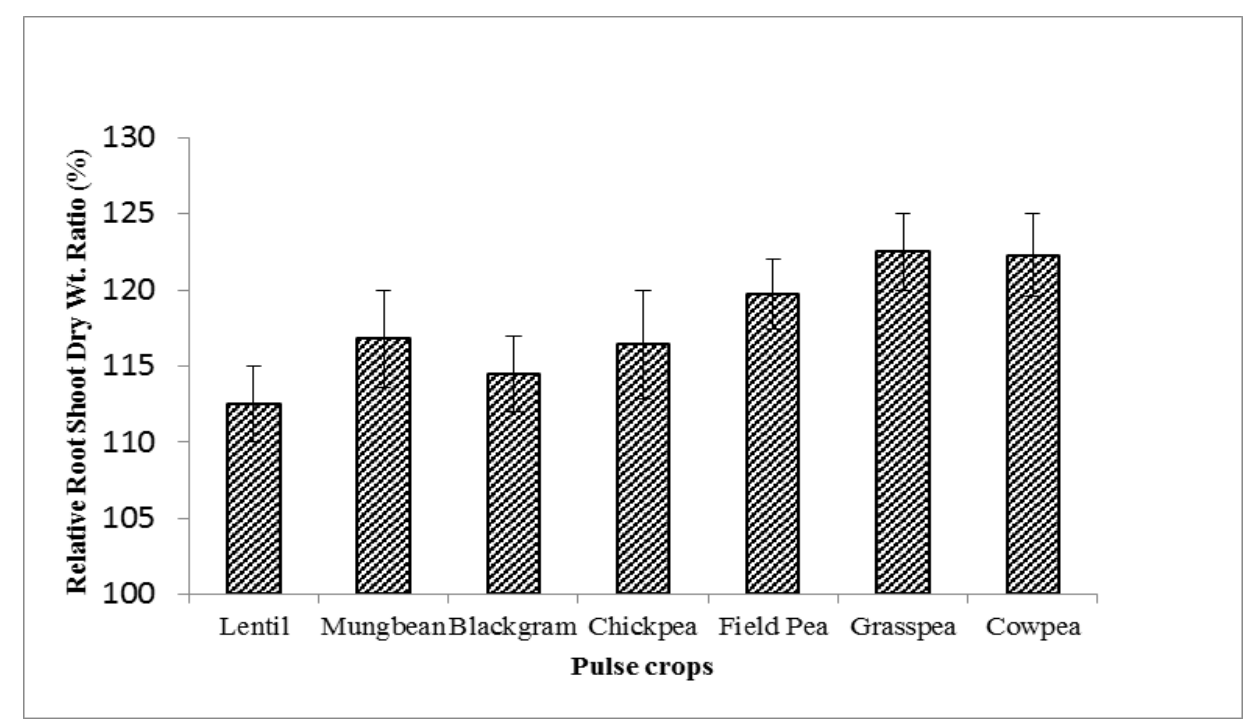

Fig. 7. Relative root and shoot dry weight ratio (\%) of seven selected pulse crops under salt stress at $8 \mathrm{dSm}-1$ used as commercial $\mathrm{NaCl}$; vertical bar represents SE.

Salinity may directly or indirectly inhibit cell division, cell enlargement, which results in reduction of shoot length, number of leaves, dry matter accumulation, leaf size, mobilization of food material from source to sink and increased root shoot ratio (Mass and Poss, 1989).

\section{Relative Stem Xylem Area (\%)}

Salinity showed a subtractive effect on shoot anatomy of pulse crops. It is indicated that, with the increase in salinity level, there was a significant decrease in stem xylem and phloem area. Relative stem xylem area (\%) was reduced due to salinity stress of seven selected pulse crops (Figure 8). 


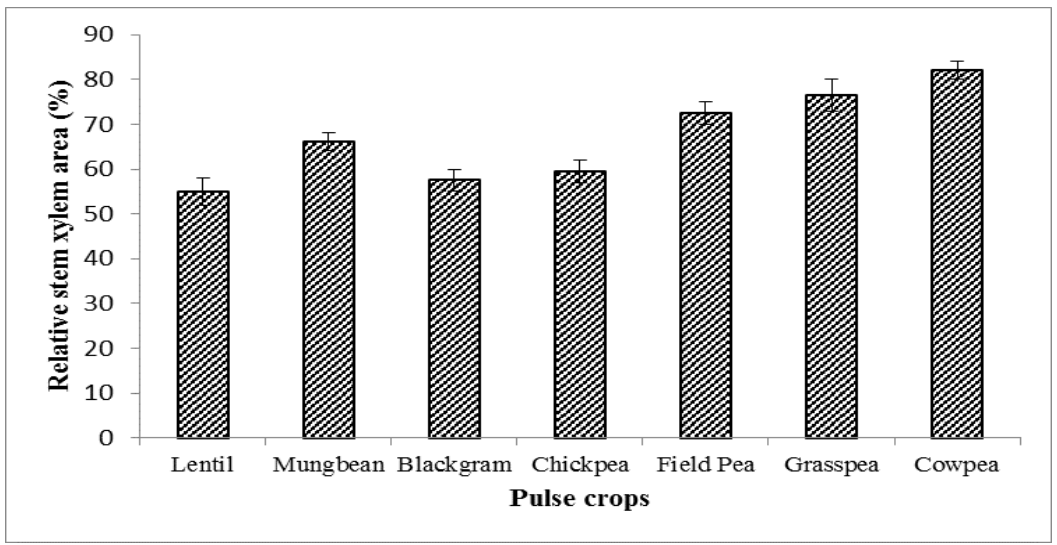

Fig. 8. Relative stem xylem area (\%) of seven pulse crops under salt stress at $8 \mathrm{dS}$ m-1 used as commercial $\mathrm{NaCl}$; vertical bar represents $\mathrm{SE}$.

However, the highest relative xylem area $(82 \%)$ was observed in cowpea followed by $(76.5 \%)$ grass pea and the lowest $(55 \%)$ in lentil. Salinity affects plant growth through osmotic effects and ion toxicity.

\section{Relative Stem Phloem Area (\%)}

Salinity also reduced the phloem area of different pulse crops compare to control condition (Figure 9). But lower reduction percentage was observed in cowpea and grass pea compare to other pulses due to salinity stress condition. However, the relative stem phloem area (\%) was observed in cowpea followed by grasspea and the lowest was found in lentil followed by black gram. Younis et al. (2014) reported that xylem and phloem area of stem showed a decreasing trend under salt stress condition which indicates that with the increase in salinity level there was noticeably decrease in the xylem and phloem cell growth.

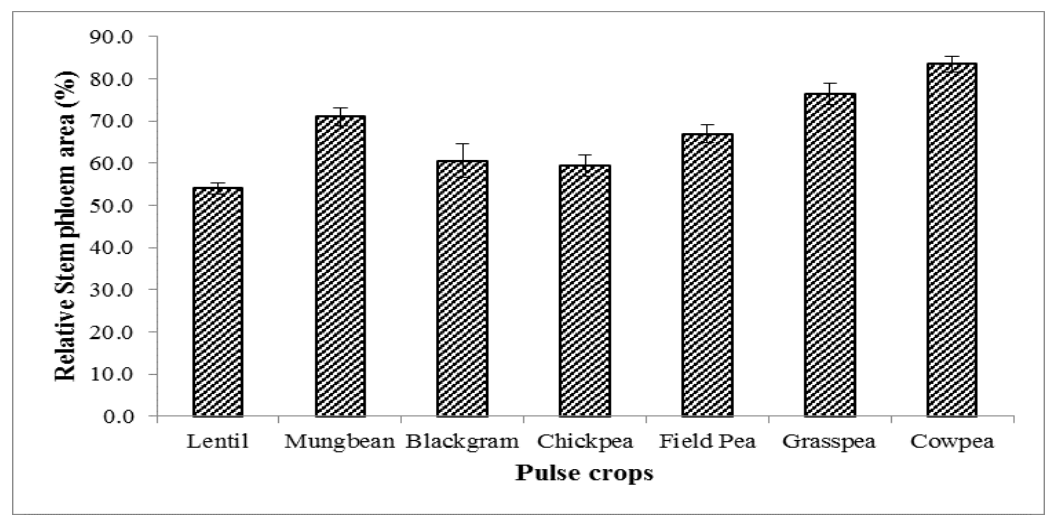

Fig. 9. Relative stem phloem area (\%) of seven pulse crops under salt stress at $8 \mathrm{dS}$ m-1 used as commercial $\mathrm{NaCl}$; vertical bar represents $\mathrm{SE}$. 
Xylem area and phloem area was maximum under normal soil (control) condition. This indicates that salinity induces structural changes in xylem and phloem of stems. The increasing salinity reduces the stems vascular area while cell thickness increased with salinity level compared to control treatment. Salinity caused the gradual changes in plant internal structure which reduces the xylem and the phloem area (Hameed et al., 2010).

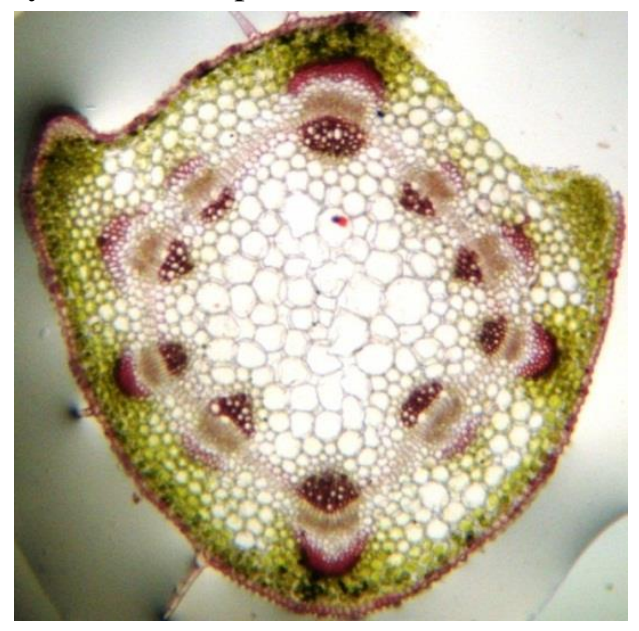

A. BARI Maskalai 1 (Stem) Salt: $8 \mathrm{dS} \mathrm{m}{ }^{-1}$

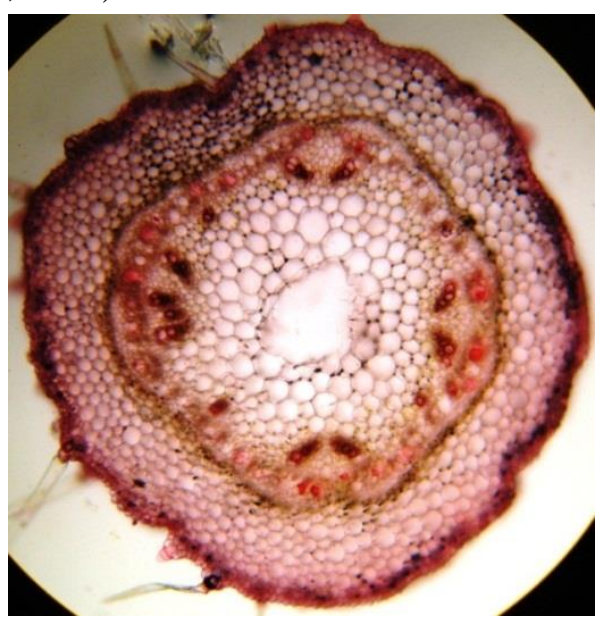

B. BARI Maskalai 1 (stem) Control

Plate 1: Transverse section of stem of black gram showing the effect of salinity seen under digital compound microscope (Model Primo star Zeiss) at 40X.

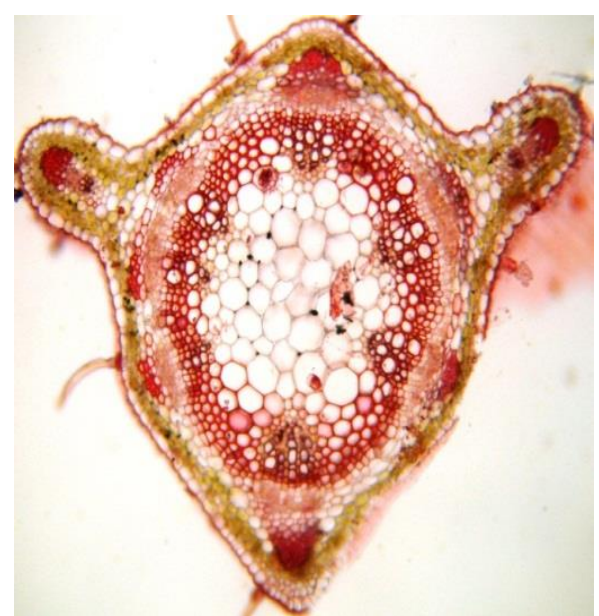

A. BARI Masur 7 (Stem) Salt: 8dS m ${ }^{-1}$

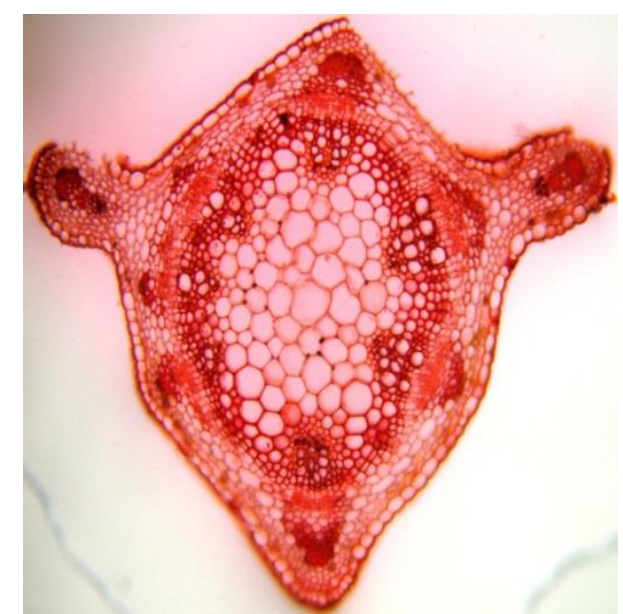

BARI Masur 7 (Stem) Control

Plate 2. Transverse section of stem of lentil showing the effect of salinity seen under digital compound microscope (Model Primo star Zeiss) at 40X. 


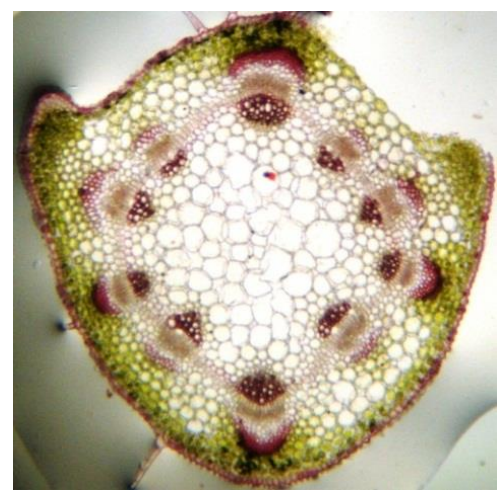

A. BARI Chola 9 (Stem) Salt: $8 \mathrm{dS} \mathrm{m} \mathrm{m}^{-1}$

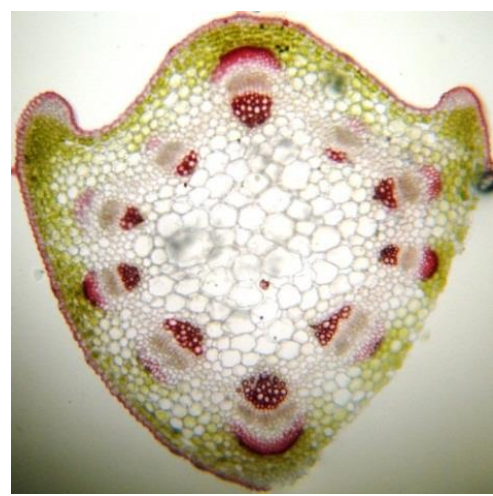

BARI Chola 9 (Stem)-Control

Plate 3. Transverse section of stem of chickpea showing the effect of salinity seen under digital compound microscope (Model Primo star Zeiss) at 40X.

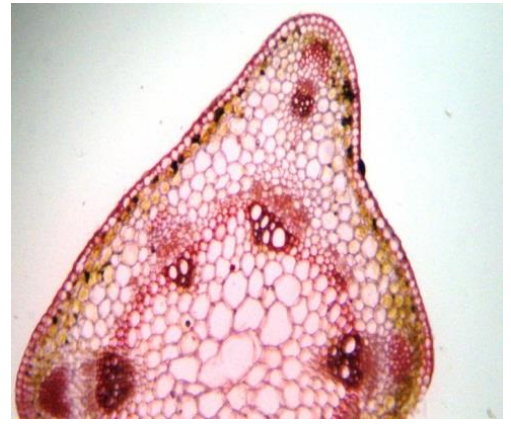

A. BARI Motor 1 (Stem) Salt: $8 \mathrm{dS} \mathrm{m}{ }^{-1}$

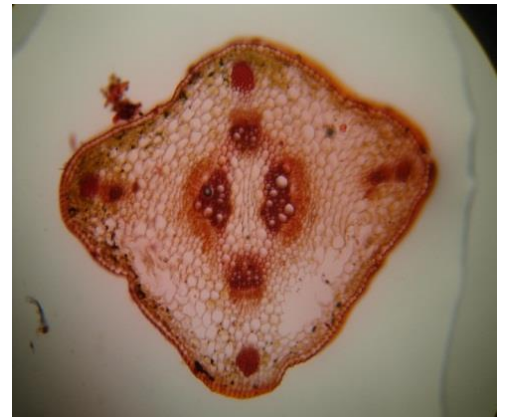

BARI Motor 1 (Stem) Control

Plate 4. Transverse section of stem of field pea showing the effect of salinity seen under digital compound microscope (Model Primo star Zeiss) at 40X.

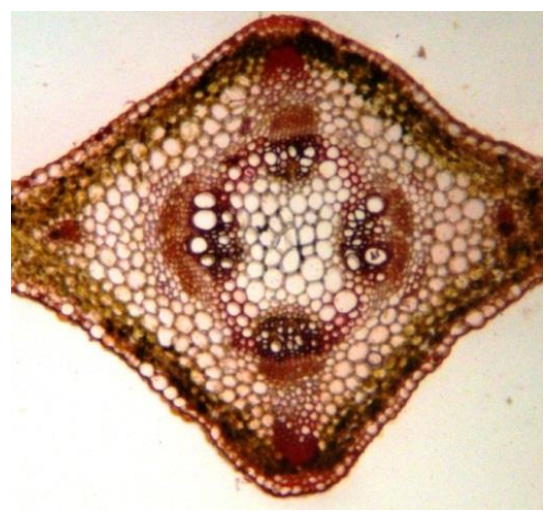

A. BARI Khesari 3 (Stem) Salt: $8 d S$ m $^{-1}$

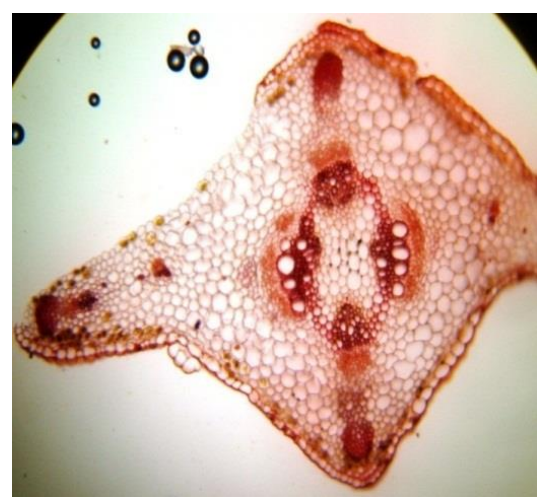

B. BARI Khesari 3 (Stem)-control

Plate 5. Transverse section of stem of grass pea showing the effect of salinity seen under digital compound microscope (Model Primo star Zeiss) at 40X. 


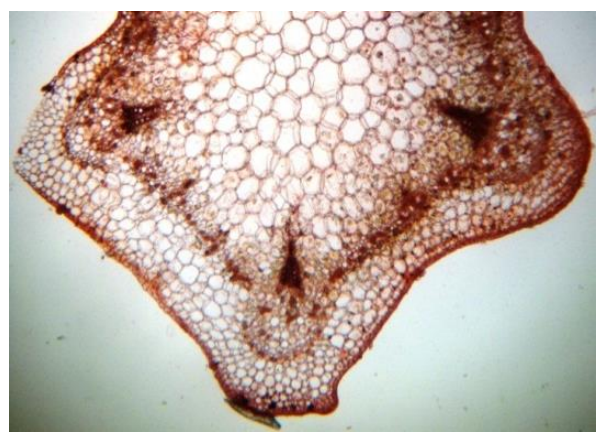

A. BARI Felon 2 (Stem) Salt: $8 \mathrm{dS} \mathrm{m}{ }^{-1}$

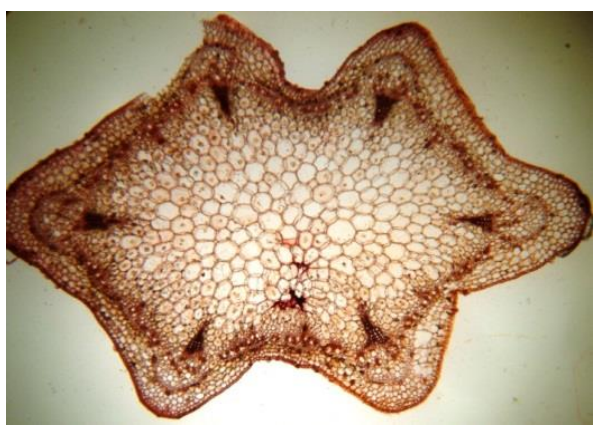

B. BARI Felon 2 (Stem) Control

Plate 6. Transverse section of stem of cowpea showing the effect of salinity seen under digital compound microscope (Model Primo star Zeiss) at 40X.

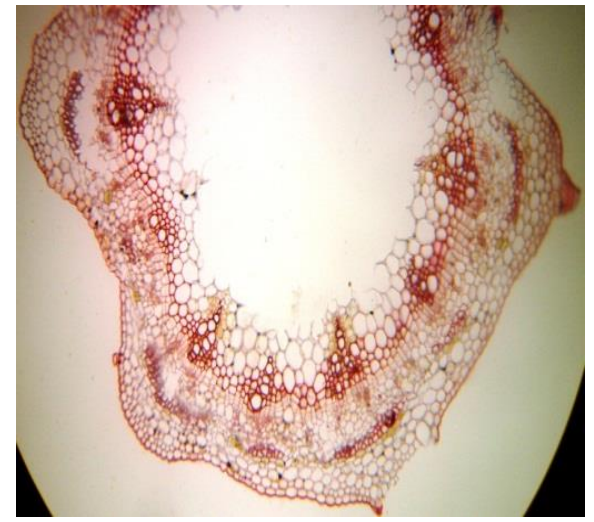

A. BARI Mung 6 (Stem) Salt: $8 \mathrm{dS} \mathrm{m} \mathrm{m}^{-1}$

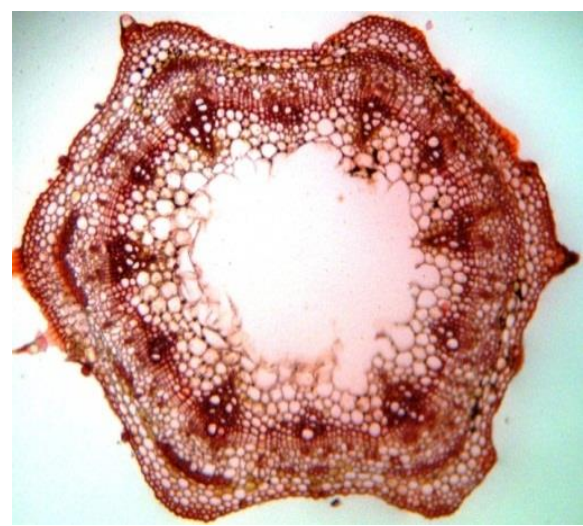

B. BARI Mung 6 (Stem) Control

Plate 7. Transverse section of stem of mungbean showing the effect of salinity seen under digital compound microscope (Model Primo star Zeiss) at 40X.

\section{Conclusion}

In morphological study, it was found that, the plant height, root length were shorter in size and shape under salinity stress condition than normal condition. Root dry weight and shoot dry weight were also reduced due to salinity stress than normal condition. The anatomical features were found some changes in stem xylem and phloem area. Some xylem and phloem size were reduced which might be the cause of lack of nutrients and water supply for physiological drought. Among the pulse crops cowpea (BARI Felon-2) and grass pea (BARI Khesari-3) were given better performance than the others whereas lentil (BARI Masur-7) and black gram (BARI Maskalai-1) were found more susceptible pulse crops according to their morphological and anatomical characteristics. 


\section{References}

Bandeoglu, E., G, F. Eyido, M. Yücel and H. A. Oktem. 2004. Antioxidant responses of shoots and roots of lentil to NaCl-salinity stress. Plant Growth Regul. 42: 69-77

Bangladesh Bureau of Statistics (BBS). 2017. Statistical yearbook of Bangladesh Statistics Division, Ministry of Planning, Government of the People's Republic of Bangladesh, Dhaka.

Dickison, W. C. 2000. Integrative Plant Anatomy. Massachusetts: Harcourt/Academic Press.

Duzdemiro, A. K. and A. Unlukara. 2009. Response of pea (Pisum sativum) to salinity and irrigation water regime. Bulg. J. Agric. Sci. 15 (5): 400-409.

Garg, N. and N. Manchanda. 2009. Role of arbuscular mycorrhizae in the alleviation of ionic osmotic and oxidative stresses induced by salinity in Cajanus cajan (L.) Millsp. J. Agron. Crop Sci. 195: 110-123.

Gomez, K. A. and A. A. Gomez. 1984. Statistical procedures for Agricultural Research. $2^{\text {nd }}$ ed. John, Wiley and Sons, New York, USA.

Hameed, M., M. Ashraf, N. Naz and F. Al-Qurainy. 2010. Anatomical adaptations of Cynodon dactylon (L.) pers., from the salt range Pakistan, to salinity stress. I. root and stem anatomy. Pak. J. Bot. 42: 279-289.

Hameed, M., M. Ashraf, N. Naz, T. Nawaz, R. Batool, M. S. A. Ahmad and M. Hussain. 2013. Anatomical adaptations of Cynodon dactylon (L.) Pers. from the salt range (Pakistan) to salinity stress. II. Leaf anatomy. Pak. J. Bot. 45: 133-142.

Kabir, M.E., M.A. Karim and M.A.K. Azad. 2004. Effect of potassium on salinity tolerance of mungbean (Vigna radiata L. Wilczek). J. Biol. Sci. 4: 103-110.

Katerji, N., J.W. Van-Hoorn, A. Hamdy, M. Mastrorilli, T. Oweis and W. Erskine. 2001. Response of two varieties of lentil to soil salinity. Agric. Water Manag. 47:179-190.

Katerji, N., J.W. Van Hoorn, A. Hamdy, M. Mastrorilli, T. Oweis and W. Erskine. 2005. Salt tolerance analysis of chickpea, faba bean and durum wheat varieties. I. Chickpea and faba bean. Agric. Water Manag. 72: 177-194.

Kaya, M.D., G. Kaya and O. Kolsarici. 2005. Effects of $\mathrm{NaCl}$ concentration on germination and emergence of some Brassica Species. J. Agric. Sci. 11: 448-452.

Marcum, K. B., S. J. Anderson and M. C. Engelke. 1998. Salt gland ion secretion: A salinity tolerance mechanism among five zoysa grass species. Crop Sci. 38: 806-810.

Mass and Poss .1989. Salt sensitivity of wheat at various growth stages. Irrig. Sci. 10: 294-320.

Ouji A., S.E. Bok, M. Mouelhi, M.B. Younes and M. Kharrat. 2017. Effect of salinity stress on germination of five Tunisian lentils (lens culinaris l.) genotypes. Eur. Sci. J. 11(21): 1857-7431

Rao, D. L. N., K. E. Giller, A. R. Yeo and T. J. Flowers. 2002. The effects of salinity and sodicity upon nodulation and nitrogen fixation in chickpea (Cicer arietinum). Ann. Bot. 89: 563-570. 
Rowell, D.L., 1994. The preparations of saturation extracts and the analysis of soil salinity and sodicity. In: Soil Science Methods and Applications, Rowell, D. L. (Ed.). Longman Group, UK.

Schleiff, U. 2008. Analysis of water supply of plants under saline soil conditions and conclusions for research on crop salt tolerance. J. Agron. Crop Sci. 81: 1-8.

Shaheenuzzamn, M. 2014. Screening of chickpea genotypes against salinity stress. Bangladesh J. Agril. Res, 39(4): 605-619.

Taffouo, V. D., M. Kenne, T. R. Fokam, W. O. Fotsop, T. Fonkou, Z. Vondo and Amougou, Akoa. 2004. Response and stress saline chezcinqe species de Légumine uses. Agronomic Afr. J. Agron. 16: 33-44.

Younis, A., A. Riaz, I. Ahmed, M. I. Siddique, U. Tariq, M. Hameed and M. Nadeem. 2014. Anatomical changes induced by Nacl stress in root and stem of Gazania harlequin. Ag. communications 2(3): 8-14.

Footnote: The experiment was conducted under the part of $\mathrm{PhD}$ research work, funded by "Establishment of Digital Herbarium and Herbal Museum for Improving Academic and Research Capability in Crop Botany" HEQEP CP-3084, UGC, Department of Crop Botany, Bangabandhu Sheikh Mujibur Rahman Agricultural University, Gazipur. 
